\title{
DEMOCRACIA DE GÊNERO E SEUS DASAFIOS: COMO AS AÇÕES AFIRMATIVAS PARA PARTICIPAÇÃO FEMININA NA POLÍTICA DEVEM SER APRIMORADAS
}

GENDER DEMOCRACY AND ITS CHALLENGES: HOW AFFIRMATIVE ACTION FOR FEMALE ENGAGEMENT IN POLITICS MUST BE IMPPROVED

\section{Marilda de Paula Silveira*}

\begin{abstract}
RESUMO
Diante da inegável constatação da sub-representação feminina na política, o presente artigo realizara análise acerca dos motivos que são apontados como causa desse quadro de sub-representação. Traça, ainda, panorama sobre a legislação brasileira, as principais inovações normativas e as alterações jurisprudências voltadas a promover maior participação das mulheres na vida política. Avalia como a jurisprudência do Tribunal Superior Eleitoral e do Supremo inovaram na implementação de ações afirmativas com o objetivo de ampliar a representação feminina nas esferas democráticas. Examina-se os efeitos dessas normas e sua efetividade bem como propostas que vêm sendo apresentadas como alternativa para se alcançar maior isonomia entre os gêneros nas esferas político-decisórias.
\end{abstract}

PALAVRAS-CHAVE: Sub-representação feminina. Política. Gênero. Mulheres. Cotas. Mandato.

\begin{abstract}
In view of the undeniable recognition of female underrepresentation in politics, this article analyzes the reasons that are cited as the cause of this underrepresentation. It also outlines the Brazilian legislation and the main normative innovations aimed at promoting greater participation of women in political life, as well as the way in which the jurisprudence of the Superior Electoral Court has applied these rules. It examines the effects of these norms and their effectiveness as well as proposals that have been presented as an alternative to achieve greater gender equality in the political decision-making spheres.
\end{abstract}

KEYWORDS: Female underrepresentation. Policy. Genre. Women. Quotas. Mandate.

\section{INTRODUÇÃO: ANÁLISE DO CENÁRIO DE REPRESENTAÇÃO FEMININA}

Poucos temas são tão consensuais na ciência política e no estudo do sistema eleitoral brasileiro quanto a predominância masculina no exercício dos mandatos, sejam eles eletivos, estejam eles situados no âmbito interno da representação partidária. Os números, sempre citados, falam por si.

A despeito de serem responsáveis pela manutenção de cerca de $40 \%$ das famílias brasileiras, ocuparem $41,9 \%$ dos postos de trabalho e comporem

Mestre e doutora em Direto Público pela UFMG. Professora de Direito Administrativo e Eleitoral do IDP/EDB. Membro do IBRADE e ABRADEP. Pesquisadora do CEDAU/USP. Coordenadora da Transparência Eleitoral Regional Brasil. Advogada sócia da Silveira e Unes Advogados Associados.E-mail: marilda.silveira@idp.edu.br 
$52 \%$ do eleitorado do país ${ }^{1}$, as mulheres representam apenas $10 \%$ do total de parlamentares da Câmara dos Deputados e 16\% do Senado. Dos 35 partidos registrados no TSE, apenas 4 são presididos por mulheres ${ }^{2}$. Além do mais, dentre os 28 partidos que elegeram deputados federais, 11 não contam com nenhuma mulher entre os seus representantes e, nada menos do que 16 estados da federação não possuem representação feminina no Senado Federal ${ }^{3}$.

Em pesquisa recentemente realizada pela União Interparlamentar (IPU) ${ }^{4}$, a baixíssima representatividade das mulheres no Congresso Nacional colocou o país na $154^{\mathrm{a}}$ posição dentre 188 nações pesquisadas, ficando à frente apenas de alguns países árabes e de ilhas polinésias. Quando comparado a seus vizinhos latino-americanos, o Brasil apresenta a penúltima pior situação, precedendo apenas o Haiti. Em outro estudo, realizado pelo Projeto Mulheres Inspiradoras ${ }^{5}$, a partir de dados do Banco Mundial (Bird) e do Tribunal Superior Eleitoral, a conclusão não é diferente: dentre os 138 países analisados, o Brasil ficou na $115^{\circ}$.

No âmbito estadual e municipal, a situação não é menos grave. Nas eleições de 2014, uma única mulher foi eleita governadora, e apenas 11\% das cadeiras nas Assembléias Legislativas foram ocupadas por representantes do sexo feminino. Os dados do TSE apontam, ainda, que entre os 5.485 prefeitos eleitos em 2016, apenas $640(12 \%)$ são mulheres e, no legislativo municipal, o percentual de representantes do sexo feminino não passa dos $14 \%{ }^{6}$.

Felizmente, o cenário da representatividade feminina na política é bastante distinto em muitas nações estrangeiras, podendo-se destacar dentre elas Ruanda, Bolívia e os países nórdicos (Noruega, Suécia, Finlândia e Dinamarca), onde o percentual de mulheres no Parlamento chega a ultrapassar os 50\%. Embora se localizem em diferentes regiões do globo e apresentem níveis de desenvolvimento sócio-econômico bastante díspares, o traço comum entre essas nações é a adoção de medidas voltadas a promover maior igualdade de condições no jogo político, a partir de regras inseridas em seu sistema eleitoral. ${ }^{7}$

1 De acordo com os dados do Tribunal Superior Eleitoral. Disponível em: <http://www.tse.jus. br/eleicoes/estatisticas/estatisticas-eleitorais-2016/eleicoes-2016>. Acesso em: 11 de março de 2019.

2 PT, PCdoB, PODEMOS e PMB. http://www.tse.jus.br/partidos/partidos-politicos/registradosno-tse. Acesso em 11 de março de 2019.

3 Dados fornecidos pela cartilha “+ Mulheres na Política”, desenvolvida em conjunto pela Procuradoria Especial da Mulher do Senado Federa e Secretaria da Mulher na Câmara. Disponível em: <https://www12.senado.leg.br/institucional/procuradoria/proc-publicacoes/ livreto-mais-mulheres-na-politica>. Acesso em 11 de março de 2019.

4 Disponível em: <http://www.ipu.org/wmn-e/classif.htm>. Acesso em 10 de agosto de 2017

5 Disponível em: <http://www.marlenecamposmachado.com.br/documentos/pequisa-presencafeminina-no-parlamento.pdf>. Acesso em: 11 de março de 2019.

6 Disponível em: <http://www.tse.jus.br/eleicoes/estatisticas/estatisticas-candidaturas-2014/ estatisticas-eleitorais-2014-resultados>. Acesso em 11 de março de 2019.

7 Disponível em: < https://beta.ipu.org/resources/publications/infographics/2017-03/ 
Apesar dos exemplos de sucesso na implementação de medidas efetivas para a maior inclusão de mulheres nos centros de poder, de acordo com a União Interparlamentar, em termos globais, a média de participação das mulheres ainda é de cerca de $23 \%{ }^{8}$, percentual que evidencia que a sua sub-representação na política é uma questão extremamente disseminada, demandando reflexão e esforços conjuntos do legislador, dos agentes políticos e da sociedade para sua superação.

Diante desse cenário, e buscando fomentar o debate acerca da participação feminina na política, o presente artigo realizará uma análise acerca dos motivos que são apontados como causa desse quadro de sub-representação, das previsões normativas e decisões judiciais que buscaram - ou ainda buscam - implementar ações afirmativas nesse sentido e dos efeitos que essas normas produziram na sociedade. Ao fim, pretende-se descortinar os fatores que se colocam como barreiras à presença feminina nas esferas político-decisórias e quais seriam os incentivos das ações afirmativas que, algumas vezes, atingem finalidade diversa da pretendida.

\section{SUBREPRESENTAÇÃO FEMININA: O QUE A LITERATURA APRESENTA COMO RAZÕES DE MANUTENÇÃO DO STATUS QUO}

Há pouco mais de quatro décadas, o histórico de desequiparação legal entre homens e mulheres vem se dissipando. Esse quadro foi confirmado e ampliado pela Constituição de 1988 que assegura igualdade independentemente do gênero.

Ocorre que o reconhecimento constitucional e legal dessa igualdade não foi suficiente para assegurar que as mulheres ocupassem o mesmo espaço que os homens na representação democrática. Diante dos índices expostos acima, não se pode deixar de indagar por que a igualdade formal não foi capaz de garantir que as mulheres ocupassem, de forma equivalente, os mandatos eletivos.

Essa não é uma análise pouco complexa. Repensar a origem do problema da sub-representação feminina na política, levantando suas causas é certamente um passo de extrema importância para que se possa vislumbrar caminhos de superação. Somente assim não se corre o risco de alcançar efeitos colaterais mais danosos que os benefícios alcançados com eventuais alterações legislativas.

Para compreender a sub-representação feminina na vida política brasileira, não se pode perder de vista que até 1962 a mulher era considerada relativamente

women-in-politics-2017?utm_source=Inter-Parliamentary+Union+\%28IPU\% 29\&utm_ campaign=550dedbec7-EMAIL_CAMPAIGN_2017_02_23\&utm_medium=email\&utm_ term=0_d1ccee59b3-550dedbec7-258891957>. Acesso em 11 de março de 2019.

8 Disponível em: <https://beta.ipu.org/resources/publications/infographics/2017-03/women-in-politics2017?utm_source=Inter-Parliamentary+Union+\%28IPU\%29\&utm_campaign=550dedbec7EMAIL_CAMPAIGN_2017_02_23\&utm_medium=email\&utm_term=0_d1ccee59b3550dedbec7-258891957>. Acesso em 11 de março de 2019. 
incapaz e dependia do seu marido para exercer inúmeros direitos ${ }^{9}$. Foi com o estatuto da mulher casada, Lei 4.121/62, que parte das desigualdades e essa noção de incapacidade foi revogada. Não se tratava, portanto, de simples questão cultural, mas de opção normativa incorporada ao Estado de Direito vigente, amparada por política estatal que se pautava exclusivamente pelo gênero.

Há pouco mais de 30 (trinta anos), em 1985, as pesquisadoras Albertina de Oliveira Costa, Carmen Barroso e Cynthia Sarti, da Fundação Carlos Chagas, fizeram um levantamento bibliográfico das pesquisas sobre as mulheres, realizadas no Brasil, entre 1976 e 1985, e apontam como fatores que dificultaram o trabalho: a "novidade relativa do assunto" e o "terreno de convergência possivel entre diferentes disciplinas e terra de ninguém"10

No mesmo período, em 1987, a Professora Titular de História da FFLCH escreveu um artigo em que explicava como era difícil estudar a história da mulher brasileira ${ }^{11}$ porque a "estrutura universitária [era] demasiadamente conservadoras". Naquele momento, narrava a professora que "a História da Mulher ainda é encarada como 'coisa de feminista' ou então como simples curiosidade fútil num leque de disciplinas que se propõe transmitir o essencial do saber histórico" 12 .

9 Maria Lygia Quartim de Moraes: "Com o casamento, a mulher perdia sua capacidade civil plena. Cabia ao marido a autorização para que ela pudesse trabalhar, realizar transações financeiras e fixar residência. Além disso, o Código Civil punia severamente a mulher vista como 'desonesta', considerava a não virgindade da mulher como motivo de anulação do casamento (...) e permitia que a filha suspeita de 'desonestidade', isto é, manter relações sexuais fora do casamento, fosse deserdada". Moraes, Maria Lígia Quartim - "Cidadania no feminino": In Pinsky, J. e Pinsk, C B, História da Cidadania, Ed. Contexto, SP, 2003.

10 COSTA, Albertina de Oliveira, BARROSO, Carmen Barroso e SARTI, Cynthia. Pesquisa sobre mulher no Brasil do limbo ao gueto. Cad. Pesquisa, São Paulo (54): 5-15. p. 5, agosto, 1995. Disponível em: <file:///C:/Users/Marco\%20Aurelio/Downloads/1389-5271-1-PB.pdf> Acesso em: 03 june 2018.

11 Logo no início do artigo a Professora Maria Beatriz Nizza da Silva relata: "Área do saber ainda imprecisamente demarcada, pretendendo-se interdisciplinar, os estudos sobre a mulher dificilmente se impõem e ganham autonomia na estrutura universitária brasileira, demasiado conservadora para abandonar as disciplinas a muito cristalizadas. De todas as Universidades talvez a Universidade de São Paulo seja a mais difícil de abalar. Enquanto em outras, mais flexiveis, já existem desde 1981 núcleos de estudos sobre a mulher (nas Universidades Federais do Cerará, Paraíba, Bahia, Minas Gerais e Rio Grande do Sul e nas Universidades Católicas do Rio de Janeiro e São Paulo), só em 1985 docentes pesquisadores da Universidade de São Paulo se reuniram para fazer um levantamento de todos os cursos e pesquisas que tivessem como objeto a mulher e as relações de gênero. Constituiu-se então o núcleo Mulher que lançou o seu primeiro Boletim em maio de 1986, com informações sobre os seminários organizados nesse ano ("A mulher em sociedades negro-africanas", "A violência contra a mulher", "O aborto", "Igreja, concubinato, bastardos e mães solteiras") e também sobre cursos ministrados no Departamento de Ciências Sociais especificamente sobre a mulher ("Mulher, trabalho e participação política" e "Mulher, sexualidade e trabalho")".

12 SILVA, Maria Beatriz Nizza da. A história da mulher no Brasil: tendências e perspectivas. Revista do Instituto de Estudos Brasileiros, São Paulo, n. 27, p. 75-91, dec. 1987. ISSN 2316901X. Disponível em: <http://www.revistas.usp.br/rieb/article/view/69910>. Acesso em: 11 de março de 2019. doi:http://dx.doi.org/10.11606/issn.2316-901X.v0i27p75-91. 
Não é irrelevante, nesse contexto, o fato de que nossa sociedade é composta por aqueles que viveram, foram criados ou são herdeiros do que previa o Código Civil de 1916. Essa constatação reflete a posição cultural de $81 \%$ dos homens brasileiros, os quais consideram viver em uma sociedade machista que reforma estereótipos do que seria papel do homem e da mulher. ${ }^{13}$

Não surpreende, portanto, que a sociedade não tenha absorvido culturalmente esse critério de igualdade e que as normas que prevejam requisitos de acesso a partir de uma igualdade formal acabem por aprofundar a exata medida da desigualdade.

É possível que as mulheres não queiram ocupar espaços de poder, ainda que eles estejam tão disponíveis quanto para os homens? É possível que a natureza da atividade política afaste as mulheres dos mandatos eletivos? É possível que as diferenças próprias do gênero impulsionem escolhas profissionais diversas ${ }^{14}$ ? É possível que a corrupção afaste as mulheres da política ${ }^{15}$ ?

Não há dúvida de que a resposta a essas questões pode ser positiva. Contudo, o acesso às respostas somente seria possível se os mandatos eletivos fossem, de fato, acessíveis às mulheres em igualdade de condições com os homens. De modo que a decisão por disputar um mandato eletivo fosse realmente viável, sem que a questão de gênero se apresentasse, em si, como fator de desequilíbrio.

A literatura apresenta explicações de natureza as mais diversas para essa sub-representação ${ }^{16}$, incluindo a dupla jornada de trabalho, os baixos incentivos ${ }^{17}$ e o ambiente corrupto. A questão que se coloca, portanto, é saber se esse cenário decorre de diferenças naturais e deveria ser aceito (tolerado) ou se é fruto de uma

$1381 \%$ dos homens consideram o Brasil um país machista, aponta pesquisa inédita da ONU Mulheres. < http://www.onumulheres.org.br/wp-content/uploads/2018/04/Relatorio_ONU_ ElesporElas_PesquisaQuantitativa2016.pdf>

14 Sacchet (2011, p. 167): "Na fase infantil (anos de socialização na família e nas escolas) e na fase adulta, a experiência de exclusão política e de modelos e/ou imagens pouco desviantes do padrão aprendido contribuem para que as mulheres se interessem menos pela política formal e, também, sintam-se inseguras e despreparadas para a execução da função pública. Na disputa eleitoral, elas são foco de críticas morais e têm sua vida privada mais abertamente exposto que a dos homens, questões que tendem a impactar de forma diferente sua vida. Ou seja, fatores culturais influenciam a visão das mulheres e o seu interesse pela política.”

15 Esarey e Chirillo apontam que a participação política feminina é maior em democracias menos corruptas. ACKERMAN, Susan Rose et PALIFKA, Bonnie J. Corruption and Government. Second edition. Cambridge, 2016. p. 244.

16 Costa et al. 2013. Incluindo razões de ordem biológica cuja exposição (sobretudo pelo conteúdo da fala) levou à demissão de Sundar Pichai da posição que ocupava na empresa Google. O fato gerou grande repercussão.

17 Norris1997; Norris \& Lovenduski 1995. Há quem aponte razões de ordem biológica que fundamentariam a diferença das escolhas profissionais masculinas e femininas. Sundar Pichai publicou o que seria um manifesto intitulad "a bolha ideológica do Google”, em que afirma que homens e mulheres não têm as mesmas habilidades, inquietações e ambição no campo tecnológico e laboral. Esse debate (não só pelo mérito, mas pelo conteúdo da fala) levou à demissão do ex-executivo e gerou grande repercussão. < https://brasil.elpais.com/ brasil/2017/08/06/tecnologia/1502006187_214063.html> 
história cujos atores são capazes de perpetuar uma desequiparação que não se justifica em nenhuma medida.

A escassez de mandatos os quais, historicamente, sempre foram ocupados por homens é o primeiro fator de estabilidade que dificulta a participação feminina. A partir dessa premissa forma-se um ciclo vicioso: o grupo que ocupa uma posição de poder não quer deixa-la; esse grupo detém competência constitucional para produzir as normas que regulam o acesso às posições de poder; as regras favorecem à manutenção do status quo; a composição de forças não se renova.

A dificuldade se agrava pelo fato de ser sensivelmente mais difícil eleger um candidato pela primeira vez do que reeleger alguém que já ocupa mandato eletivo. Em 2016 a taxa de reeleição de prefeitos alcançou o menor número da história recente e foi de impressionantes 47\% ${ }^{18}$. Em 2008 essa taxa era de $66 \%$.

Isso ocorre porque os titulares de mandato são conhecidos do público, executam políticas públicas e, no geral, suas plataformas políticas já estão bem definidas. É também um consenso o fato de que a posição de ocupante de uma função pública favorece, significativamente, as chances de êxito em uma nova disputa eleitoral. Nosso sistema, embora busque combater a perpetuação daqueles que estão no poder, não impõe limitação à reeleição para cargos do poder legislativo. Fato que, também, favorece a perpetuação de homens já ocupantes de mandatos no legislativo.

Pode-se afirmar, portanto, que o atual cenário político brasileiro dificulta a substituição de um homem que já seja titular de mandato por uma mulher. Disso também resulta a escassez de espaços de poder que constitui uma das barreiras à maior participação feminina na política.

O segundo fator que estaciona a participação feminina na política é a leitura que sempre se fez da autonomia partidária (art. 17 da CR/88) somada ao monopólio constitucional outorgado aos partidos políticos para lançar candidaturas. Em que pese tenha sido ampliada a discussão sobre democracia intrapartidária ${ }^{19}$, as decisões internas dos partidos ainda são consideradas interna corporis e sujeitam-se, como regra, aos estatutos. Estes, por sua vez, atribuem competência aos seus dirigentes cuja composição é basicamente masculina. Dos 35 (trinta e cinco) partidos registrados no Tribunal Superior Eleitoral, apenas 3 (três) possuem mulheres em sua presidência ${ }^{20}$. Os homens que já ocupam as

18 De acordo com dados do TSE (Tribunal Superior Eleitoral 2.945 prefeitos se candidataram à reeleição e 1.385 foram reeleitos.

19 As decisões partidárias (escolha dos candidatos, das coligações, da distribuição de recursos nas campanhas e do tempo de propaganda) são tomadas nos termos dos estatutos que, em sua grande maioria, atribuem à tomada de decisão aos dirigentes (sobre o tema, conferir: CAMPOS NETO, Raymundo.A Democracia interna nos partidos políticos brasileiros. Belo Horizonte: De Plácido, 2016). E estes, por sua vez - como destacado no início do trabalho são homens em sua destacada maioria.

20 http://www.tse.jus.br/partidos/partidos-politicos/registrados-no-tse Acesso em 11 de março de 
posições de poder não têm nenhum incentivo para alterar o cenário de representação desigual.

Um terceiro fator que até então afetou a participação feminina na política foram os altos custos de uma campanha eleitoral. A partir da decisão do STF na ADI 4650, a captação de recursos de pessoas jurídicas foi vedada, restando aos candidatos: as doações de pessoas físicas e as doações dos partidos (advindas de recursos próprios, do fundo partidário e do FEFC) além do tempo de propaganda eleitoral. Parte significativa dos recursos, portanto, passa por um filtro partidário que, sem democracia interna, ainda depende de decisões majoritariamente masculinas.

Recente decisão do STF na ADI $5717^{21}$ e na Consulta $252-18^{22}$ pretendeu alterar esse cenário a partir das eleições de 2018. O STF decidiu que a distribuição de recursos do Fundo Partidário destinado ao financiamento das campanhas eleitorais direcionadas às candidaturas de mulheres deveria ser feita na exata proporção das candidaturas de ambos os sexos, respeitado o patamar mínimo de $30 \%$ de candidatas mulheres e o TSE estendeu a decisão para o fundo especial de campanha.

Apesar da polêmica que cercou a destinação dos recursos para candidatas a vice e suplentes, a alteração produziu efeitos: na Câmara Federal foram eleitas 77 deputadas, um aumento de $51 \%$ em relação a 2014. O número de deputadas estaduais também cresceu $35 \%$.

Até então, os dados apontavam que as mulheres, em geral, possuem menos recursos próprios para investir, recebem menos incentivo da iniciativa privada e também são desfavorecidas na distribuição de recursos pelos partidos políticos ${ }^{23}$.

De acordo com os dados enviados à Justiça Eleitoral pelos 496.896 candidatos a prefeito e vereador nas Eleições Municipais 2016, até o final de outubro, portanto antes do segundo turno e do fim do prazo da entrega da prestação de contas do primeiro turno, especificamente no caso da eleição para vereadores, a

\section{9.}

21 Deu “interpretação conforme à Constituição ao art. $9^{\circ}$ da Lei 13.165/2015 de modo a (a) equiparar o patamar legal mínimo de candidaturas femininas (hoje o do art. $10, \mathbb{S} 3^{\circ}$, da Lei 9.504/1997, isto é, ao menos 30\% de cidadãs), ao mínimo de recursos do Fundo Partidário a lhes serem destinados, que deve ser interpretado como também de $30 \%$ do montante do Fundo alocado a cada partido, para eleições majoritárias e proporcionais, e (b) fixar que, havendo percentual mais elevado de candidaturas femininas, o mínimo de recursos globais do partido destinados a campanhas lhe seja alocado na mesma proporção".

22 "A distribuição dos recursos do Fundo Especial de Financiamento de Campanha (FEFC), previsto nos artigos 16-C e 16-D, da Lei das Eleições, e do tempo de propaganda eleitoral gratuita no rádio e na televisão, regulamentada nos arts. 47 e seguintes do mesmo diploma legal, deve observar os percentuais mínimos de candidatura por gênero, nos termos do art. 10, $\int 3^{\circ}$, da Lei $n^{\circ}$ 9.504/97, na linha da orientação firmada na Suprema Corte ao exame da ADI 5617. No caso de percentual superior de candidaturas, impõe-se o acréscimo de recursos do FEFC e do tempo de propaganda na mesma proporção".

23 SACCHET, 2011, p. 163 
média da arrecadação masculina foi de $\mathrm{R} \$ 8.286$ e a média da doação feminina foi de $\mathrm{R} \$ 4.568$. Já os partidos políticos destinaram proporcionalmente $30 \%$ mais recursos para seus candidatos a vereador homens em relação ao que foi repassado às mulheres. ${ }^{24}$

Mesmo no Partido da Mulher Brasileira (PMB), os candidatos homens receberam cerca de $42 \%$ mais recursos. Apenas candidatas de quatro partidos, entre 35 siglas, receberam mais, proporcionalmente, que os homens: Partido Social Democrático (PSD), Partido Trabalhista Brasileiro (PTB), Partido Popular Socialista (PPS) e Novo.

Pesquisa realizada pela União Interparlamentar, no ano de 2009, com 300 membros do parlamento constatou que um dos principais obstáculos para as mulheres entrarem na política foi a falta de recursos financeiros para disputar campanhas eleitorais. Essa conclusão foi corroborada em pesquisa realizada pela ONU Mulheres em 2013, em que mais de 80\% dos entrevistados apontaram a falta de acesso ao financiamento como um dos maiores desafios para a entrada de mulheres na política ${ }^{25}$.

Além das dificuldades no financiamento de campanha, a participação das mulheres na política é permeada ainda de diversos outros desafios, como a falta de apoio no bojo das agremiações partidárias, o qual fica evidente quando se verifica, por exemplo, os baixos índices de indicação de candidatas para concorrer a cargos eletivos majoritários e o pouco espaço que lhes é conferido nas propagandas políticas.

Verifica-se, portanto, que as barreias à participação feminina na política possuem diferentes ordens, perpassando questões i) sistêmicas, tendo em vista a escassez de espaços a serem ocupados; ii) culturais, eis que ainda vivemos sob uma sociedade altamente patriarcal, em que a prescrição de papéis sociais não favorece a ocupação de espaços de poder pelas mulheres e iii) institucionais, conforme se verifica pela falta de espaço conferido às mulheres no seio das instituições que compõem o sistema político do país.

Delineados os principais empecilhos à entrada das mulheres na política, passa-se a analisar a maneira como a legislação pátria vem tratando o tema, para que em seguida, seja possível averiguar a efetividade dessas normas na busca pela superação desse grave quadro de sub-representação feminina que atualmente marca a democracia brasileira.

24 Esses dados foram tirados excluindo os candidatos com zero voto.

25 BALLINGTON E KAHANE, 2015, p. 402 


\section{TRATAMENTO CONFERIDO PELA LEGISLAÇÃO BRASILEIRA À QUESTÃO DA REPRESENTATIVIDADE FEMININA NA PO- LÍTICA}

A Lei Internacional de Direitos Humanos (ONU, 1948) e Convenção da Assembleia Geral das Nações Unidas sobre Direitos Políticos da Mulher (ONU, 1954) já defendiam, no âmbito internacional, o princípio da igualdade política entre os sexos, requerendo dos Estados signatários que assegurassem a igualdade entre homens e mulheres frente aos direitos civis e políticos. $\mathrm{O}$ objetivo das normas era derrubar as barreiras legais à participação política feminina. Todavia, elas não previam instrumentos voltados à fomentar diretamente a presença de mulheres nos núcleos de poder.

No ano de 1979, com a Convenção sobre Eliminação de Todas as Formas de Discriminação Contra a Mulher ${ }^{26}$, a ONU lançou efetivamente uma agenda internacional voltada a combate da discriminação de gênero. A Convenção não só reforça o direito das mulheres ao exercício de sua capacidade eleitoral ativa, por meio do voto, mas também fomenta a participação na vida pública. Além de incentivar a participação das mulheres, ocupando cargos públicos eletivos ou não, inova-se ao propor que a adoção de políticas afirmativas voltadas à promoção da igualdade material entre homens e mulheres não será considerada discriminatória.

\section{Artigo $4^{\circ}$}

1. A adoção pelos Estados-Partes de medidas especiais de caráter temporário destinadas a acelerar a igualdade de fato entre o homem e a mulher não se considerará discriminação na forma definida nesta Convenção, mas de nenhuma maneira implicará, como conseqüência, a manutenção de normas desiguais ou separadas; essas medidas cessarão quando os objetivos de igualdade de oportunidade e tratamento houverem sido alcançados.

Na mesma direção, a chamada Plataforma de Pequim, elaborada durante a IV Conferência Mundial sobre a Mulher no ano de 1995, também defende claramente a adoção de ações afirmativas em favor da maior inclusão de mulheres na política.

Dentre as medidas propostas pelo documento estão ainda a necessidade de alcançar uma representação isonômica entre homens e mulheres em todos os postos governamentais e da administração, a adoção de medidas que estimulem os partidos políticos a incorporar as mulheres em postos eletivos e não eletivos e examinar o impacto dos sistemas eleitorais sobre a representação política das mulheres para que se possa analisar a necessidade de reforma desses sistemas.

O legislador pátrio não ficou alheio a esse cenário de baixa representatividade feminina na política, tendo implementado, ao longo das últimas duas

26 A Convenção foi incorporada ao ordenamento jurídico brasileiro por meio do Decreto 4.377, de 13 de setembro de 2002 . 
décadas, alterações nas normas que disciplinam o processo eleitoral, que têm como objetivo ampliar a participação das mulheres na vida política, conforme se passa a demonstrar.

\subsection{DA RESERVA DE VAGAS PARA CANDIDATURAS}

Apesar de as reformas eleitorais com imposição de quotas estarem previstas na Lei 9.504/1997, somente depois de 2009, com a alteração de posicionamento do TSE, é que se tornaram mais efetivas. De lá para cá, a cada eleições uma nova modificação, ampliando a ação afirmativa foi feita: indeferimento do registro de todos os candidatos do partido ou coligação que não cumpriram a quota; reconhecimento de fraude por candidaturas laranja; imposição de destinação de recursos financeiros para candidaturas de mulheres; penalização dos partidos que não atenderam a obrigação de reservar tempo de propaganda para o incentivo à participação feminina.

Nesse contexto, com o objetivo de conferir maior espaço para a participação feminina nas disputas eleitorais, foi criado no Brasil um regime de cotas para candidatos a partir da inclusão na Lei 9.504/97 de dispositivo que determina que cada partido ou coligação deverá reservar um percentual mínimo de 30\% (trinta por cento) de sua lista eleitoral para os candidatos de cada sexo. Vejamos:

Art. 10. Cada partido ou coligação poderá registrar candidatos para a Câmara dos Deputados, a Câmara Legislativa, as Assembleias Legislativas e as Câmaras Municipais no total de até $150 \%$ (cento e cinquenta por cento) do número de lugares a preencher, salvo:

\section{(...)}

$\$ 3^{\circ}$ Do número de vagas resultante das regras previstas neste artigo, cada partido ou coligação preencherá o mínimo de $30 \%$ (trinta por cento) e o máximo de $70 \%$ (setenta por cento) para candidaturas de cada sexo.

Como se verifica, o legislador brasileiro optou por estabelecer um modelo de reserva de vagas neutra de gênero, ou seja, a norma não especifica um percentual mínimo de vagas a serem preenchidos por mulheres. Todavia, no cenário atual da política brasileira, não restam dúvidas de que a regra foi pensada para garantir um mínimo de participação feminina nas eleições. Nessa direção, leciona Gomes ${ }^{27}$ :

Note-se que, conquanto se aplique indistintamente a ambos os sexos, a regra em apreço foi pensada para resguardar a posição das mulheres, que tradicionalmente não desfrutam de espaço relevante no cenário político, em geral controlado por homens, Também nesses domínios, a discriminação contra a mulher constitui desafio a ser superado.

27 GOMES, José Jairo. Curso de Direito Eleitoral. São Paulo: Saraiva, 2016, p. 367 
Acerca da relevância da adoção dessa política de reserva de vagas para candidaturas, Costa $^{28}$ afirma:

As cotas retiram o fardo do recrutamento político que pesa sobre as mulheres (como indivíduos) e o coloca sobre aqueles que controlam o processo de seleção dos candidatos, ou seja, os partidos políticos principalmente.

Destarte, as cotas forçam responsáveis pela indicação e nominação dos candidatos a se empenharem no recrutamento de mulheres, conferindo-lhes chances de participação que elas não teriam de outra forma. A norma, portanto, adota ação afirmativa voltada a conferir maior espaço para a participação feminina no processo eleitoral.

A despeito de a lei não estabelecer diretamente punições aos partidos que não preencherem as cotas, a jurisprudência do Tribunal Superior Eleitoral firmou-se no sentido de que o não atendimento aos percentuais mínimos estabelecidos pela norma implica no indeferimento do demonstrativo de regularidade dos atos partidários (DRAP). Vejamos:

AGRAVO REGIMENTAL. RECURSO ESPECIAL ELEITORAL. ELEIÇÕES 2012. DRAP. PERCENTUAIS DE GÊNERO. NÃO OBSERVÂNCIA. REEXAME. SÚMULA 7/STJ.

1. A norma prevista no art. $10, \mathbb{\$} 3^{\circ}$, da Lei $9.504 / 97$ tem caráter objetivo e o seu descumprimento impede a regularidade do registro da coligação ou do partido interessado em participar das eleições.

2. No caso, facultou-se à coligação, no prazo legal, adequar o DRAP aos percentuais de gênero, mas a determinação não foi atendida oportunamente.

3. Inviável a análise documental em recurso de natureza extraordinária para se aferir a suposta adequação do DRAP aos percentuais de gênero. Incidência, na espécie, da Súmula 7/STJ.

4. Agravo regimental não provido.

(Recurso Especial Eleitoral n ${ }^{\circ}$ 11781, Acórdão, Relator(a) Min. Fátima Nancy Andrighi, Publicação: PSESS - Publicado em Sessão, Data 06/11/2012)

Para evitar que partidos e coligações tentassem burlar a norma, sob o argumento de não possuírem candidatas em número suficiente para preencher o mínimo legal, a Corte Eleitoral passou a adotar também o entendimento de que a única alternativa cabível nesse caso é a redução do número de candidatos masculinos, para que haja adequação do percentual previsto em lei. Nesse sentido:

Registro de candidaturas. Percentuais por sexo.

1. Conforme decidido pelo TSE nas eleições de 2010 , o $\mathbb{\$} 3^{\circ}$ do art. 10 da Lei $n^{\circ} 9.504 / 97$, na redação dada pela Lei $n^{\circ} 12.034 / 2009$, estabelece a observância obrigatória dos percentuais mínimo e máximo de cada sexo, o que é aferido de acordo com o número de candidatos efetivamente registrados.

28 Costa, 2011, p. 192.

Rev. Fac. Direito UFMG, Belo Horizonte, n. 75, pp. 323-348, jul./dez. 2019 
2. Não cabe a partido ou coligação pretender o preenchimento de vagas destinadas a um sexo por candidatos do outro sexo, a pretexto de ausência de candidatas do sexo feminino na circunscrição eleitoral, pois se tornaria inócua a previsão legal de reforço da participação feminina nas eleições, com reiterado descumprimento da lei.

3. Sendo eventualmente impossível o registro de candidaturas femininas com o percentual mínimo de $30 \%$, a única alternativa que o partido ou a coligação dispõe é a de reduzir o número de candidatos masculinos para adequar os respectivos percentuais, cuja providência, caso não atendida, ensejará o indeferimento do demonstrativo de regularidade dos atos partidários (DRAP).

Recurso especial não provido.

(Recurso Especial Eleitoral no 2939, Acórdão, Relator(a) Min. Arnaldo Versiani Leite Soares, Publicação: PSESS - Publicado em Sessão, Data 06/11/2012)

Ocorre que, longe de aproveitarem a exigência legal como ponto de partida para uma maior inclusão feminina na política, as agremiações partidárias passaram empregar meios para burlar a norma insculpida no art. $10, \mathbb{} 3^{\circ}$ da Lei 9.504/97. Esse cenário deu origem às chamadas "candidaturas laranja”, que consiste no registro de candidatas que não fazem campanha, não recebem sequer um voto, e em muitos casos não têm conhecimento de que foram registradas para concorrer à eleição.

A Corte Eleitoral não se quedou inerte diante desse cenário e evoluiu sua jurisprudência, passando a adotar o entendimento de que a burla à lei perpetrada por meio de candidaturas fictícias caracteriza-se como fraude, podendo ser analisada no âmbito da ação de impugnação de mandato eletivo - AIME.

Essa importante mudança jurisprudencial ocorreu no ano de 2015, com o julgamento do REsp 149/PI ${ }^{29}$, cujo acórdão destacou a necessidade de se superar a jurisprudência segundo a qual a fraude a que se refere o art. $14, \mathbb{S} 10$, da CF, apta ensejar o ajuizamento de AIME, seria apenas aquela relativa ao processo de votação. Na ocasião, ressaltou-se que a AIME deve ser admitida como instrumento de salvaguarda da legitimidade e da normalidade das eleições contra toda sorte

29 RECURSO ESPECIAL. AÇÃO DE IMPUGNAÇÃO DE MANDATO ELETIVO. CORRUPÇÃO. FRAUDE. COEFICIENTE DE GÊNERO.

1. Não houve violação ao art. 275 do Código Eleitoral, pois o Tribunal de origem se manifestou sobre matéria prévia ao mérito da causa, assentando o não cabimento da ação de impugnação de mandato eletivo com fundamento na alegação defraude nos requerimentos de registro de candidatura.

2. O conceito da fraude, para fins de cabimento da ação de impugnação de mandato eletivo (art. 14, $\mathbb{S} 10$, da Constituição Federal), é aberto e pode englobar todas as situações em que a normalidade das eleições e a legitimidade do mandato eletivo são afetadas por ações fraudulentas, inclusive nos casos de fraude à lei. A inadmissão da AIME, na espécie, acarretaria violação ao direito de ação e à inafastabilidade da jurisdição.

Recurso especial provido.

(Recurso Especial Eleitoral no 149, Acórdão, Relator(a) Min. Henrique Neves Da Silva, Publicação: DJE - Diário de justiça eletrônico, Data 21/10/2015, Página 25-26) 
de abuso, corrupção e fraude, inclusive a fraude à lei, como ocorre nos casos de registro de candidatura fictícia.

Um ano mais tarde, no julgamento do REsp 24342/PI ${ }^{30}$, o TSE novamente se debruçou sobre o tema relativo às ações cabíveis para a apuração das chamadas “candidaturas laranja”. Discutia-se se a fraude na indicação de candidatas para atender ao percentual mínimo de candidaturas por gênero poderia ser examinada também no âmbito de ação de investigação judicial eleitoral.

O Tribunal, à unanimidade, entendeu pela necessidade de superar uma interpretação formalista do art. 22 da LC 64/90, que disciplina as hipóteses de cabimento da AIJE, consignando que a interpretação das regras previstas na Lei de Inelegibilidades, e no ordenamento jurídico eleitoral como um todo, devem ser realizadas a partir dos mandamentos constitucionais, que impõem a preservação da normalidade e legitimidade dos pleitos e a possibilidade de cassação de mandatos em razão de abuso, fraude ou corrupção. Assim, concluiu-se pela possibilidade de apuração de fraude eleitoral no preenchimento de vagas destinadas a candidaturas femininas também por meio de AIJE. Atualmente, discutem-se os efeitos que essas ações que apuram fraude terão sobre os candidatos eleitos, incluindo as mulheres.

\subsection{DESTINAÇÃO DE TEMPO DE PROPAGANDA PARA INCEN- TIVAR A PARTICIPAÇÃO FEMININA NA POLÍTICA}

Até 2016, a Lei 9.096/95 previa a existência de propaganda partidária no rádio e na televisão. Com a Lei 13.487/20147, a propaganda partidária foi extinta e, com ela, a reserva de tempo para o incentivo à participação feminina na política.

30 RECURSO ESPECIAL. AÇÃO DE INVESTIGAÇÃO JUDICIAL ELEITORAL. FRAUDE. PERCENTUAIS DE GÊNERO. CAPTAÇÃO ILÍCITA DE SUFRÁGIO.

(...)

4. É possível verificar, por meio da ação de investigação judicial eleitoral, se o partido político efetivamente respeita a normalidade das eleições prevista no ordenamento jurídico - tanto no momento do registro como no curso das campanhas eleitorais, no que tange à efetiva observância da regra prevista no art. $10, \mathbb{} 3^{\circ}$, da Lei das Eleições - ou se há o lançamento de candidaturas apenas para que se preencha, em fraude à lei, o número mínimo de vagas previsto para cada gênero,sem o efetivo desenvolvimento das candidaturas.

5. Ainda que os partidos políticos possuam autonomia para escolher seus candidatos e estabelecer quais candidaturas merecem maior apoio ou destaque na propaganda eleitoral, é necessário que sejam assegurados, nos termos da lei e dos critérios definidos pelos partidos políticos, os recursos financeiros e meios para que as candidaturas de cada gênero sejam efetivas e não traduzam mero estado de aparências.

Recurso especial parcialmente provido.

(Recurso Especial Eleitoral no 24342, Acórdão, Relator(a) Min. Henrique Neves Da Silva, Publicação: DJE - Diário de justiça eletrônico, Tomo 196, Data 11/10/2016, Página 65-66). 
Até então, o inciso IV, do art. 45, da Lei 9.096/95 31 , previa que que no mínimo $10 \%$ (dez por cento) do tempo de propaganda partidária gratuita deveria ser destinado à promoção da participação das mulheres na política. A Lei $n^{\circ}$ $13.165 / 2015$ estabeleceu uma regra de transição ${ }^{32}$ - cuja execução não chegou a ser concluída, prevendo que nas eleições de 2016 e 2018, o tempo mínimo de propaganda partidária destinadas às mulheres deveria ser de $20 \%$ e, nas eleições de 2020 e 2022, esse tempo mínimo passaria para $15 \%$.

$\mathrm{Na}$ ocasião, o TSE desempenhou papel bastante ativo no sentido de assegurar a estrita observância à norma, evitando que se criassem mecanismos de burla a esse dispositivo. Compreendeu-se que "a mera participação feminina na propaganda partidária, desvinculada de qualquer contexto relacionado à inclusão das mulheres na política, não é suficiente para atender às finalidades legais. ${ }^{33}$ "

A Corte também compreendia que no caso de descumprimento do percentual mínimo previsto em lei, ainda que parcial, a penalidade deveria ser calculada com base na integralidade do tempo de propaganda que deveria ser destinado pelo partido à difusão da participação das mulheres no cenário político. ${ }^{34}$

De outro lado, também buscando reforçar os meios de incentivo ao engajamento feminino na política, a Lei $\mathrm{n}^{\circ}$ 9.504/97, destinou ao TSE, em anos eleitorais, a utilização de até 5 (cinco) minutos diários de propaganda institucional, em rádio e televisão, para esse fim ${ }^{35}$.

31 Art. 45. A propaganda partidária gratuita, gravada ou ao vivo, efetuada mediante transmissão por rádio e televisão será realizada entre as dezenove horas e trinta minutos e as vinte e duas horas para, com exclusividade: (...)

IV - promover e difundir a participação política feminina, dedicando às mulheres o tempo que será fixado pelo órgão nacional de direção partidária, observado o mínimo de $10 \%$ (dez por cento) do programa e das inserções a que se refere o art. 49. (Redação dada pela Lei n ${ }^{\circ} 13.165$, de 2015)

32 Lei $13.165 / 2015$

Art. 10. Nas duas eleições que se seguirem à publicação desta Lei, o tempo mínimo referido no inciso IV do art. 45 da Lei no 9.096, de 19 de setembro de 1995, será de 20\% (vinte por cento) do programa e das inserções.

Art. 11. Nas duas eleições que se seguirem à última das mencionadas no art. 10, o tempo mínimo referido no inciso IV do art. 45 da Lei n 9.096, de 19 de setembro de 1995, será de $15 \%$ (quinze por cento) do programa e das inserções.

33 Recurso Especial Eleitoral n 15512, Acórdão, Relator(a) Min. Luciana Christina Guimarães Lóssio, Publicação: DJE - Diário de justiça eletrônico, Data 05/05/2016

34 esse sentido, confira-se: REsp n ${ }^{\circ}$ 12637, Relator(a) Min. Luciana Lóssio, Publicação: DJE Data 20/04/2017; Rp nº 29135, Relator(a) Min. Antonio Herman De Vasconcellos E Benjamin, Publicação: DJE - Data 20/03/2017.

35 Art. 93-A. O Tribunal Superior Eleitoral, no período compreendido entre $1^{\circ}$ de abril e 30 de julho dos anos eleitorais, promoverá, em até cinco minutos diários, contínuos ou não, requisitados às emissoras de rádio e televisão, propaganda institucional, em rádio e televisão, destinada a incentivar a participação feminina na política, bem como a esclarecer os cidadãos sobre as regras e o funcionamento do sistema eleitoral brasileiro. (Redação dada pela Lei $\mathrm{n}^{\circ}$ 13.165, de 2015) 


\subsection{DESTINAÇÃO DO FUNDO PARTIDÁRIO E DO FEFC}

Outro mecanismo empregado pelo legislador com o objetivo de buscar uma maior isonomia de gêneros no cenário político-partidário consiste na reserva de $5 \%$ (cinco por cento) do fundo partidário para a criação e manutenção de programas voltados ao incentivo da participação feminina na política. Essa inovação foi inicialmente introduzida pela Lei $n^{\circ} 12.034 / 2009$, que incluiu o inciso V, ao art. 44 da Lei no 9096/95.

Posteriormente, no intuito de conferir maior eficácia às mudanças havidas em 2009, a Lei 13.165/2015 alterou o dispositivo legal, estabelecendo que a criação e manutenção dos programas aos quais serão destinados os recursos do Fundo Partidário é atribuição da secretaria da mulher do partido e na falta desta, de seu instituto ou fundação ${ }^{36}$.

A chamada minirreforma eleitoral de 2015 também elevou a pena aplicada às agremiações que descumprirem o quanto previsto pelo inciso V. Alterou-se o $\$ 5^{\circ}$, do art. $44^{37}$, aumentando de $2,5 \%$ (dois inteiros e cinco décimos por cento) para $12,5 \%$ (doze inteiros e cinco décimos por cento) o montante que deverá ser aplicado no exercício financeiro subsequente, em programas de promoção e difusão da participação feminina, pelos partidos que não tenham empregado no ano anterior o percentual mínimo de $5 \%$ (cinco por cento) para tal finalidade .

A Lei $13.165 / 2015$ incluiu, ainda, os parágrafos $5^{\circ}$-A e $7^{\circ}$, ao art. 44, por meio dos quais passou a ser possível que as agremiações acumulem os fundos previstos no inciso $\mathrm{V}$, em contas bancárias específicas, para futura utilização em campanhas eleitorais de candidatas do partido ${ }^{38}$.

36 Art. 44. Os recursos oriundos do Fundo Partidário serão aplicados: (...)

V - na criação e manutenção de programas de promoção e difusão da participação política das mulheres, criados e mantidos pela secretaria da mulher do respectivo partido político ou, inexistindo a secretaria, pelo instituto ou fundação de pesquisa e de doutrinação e educação política de que trata o inciso IV, conforme percentual que será fixado pelo órgão nacional de direção partidária, observado o mínimo de $5 \%$ (cinco por cento) do total;

37 Art. $44(\ldots)$

$5^{\circ} \mathrm{O}$ partido político que não cumprir o disposto no inciso $\mathrm{V}$ do caput deverá transferir o saldo para conta específica, sendo vedada sua aplicação para finalidade diversa, de modo que o saldo remanescente deverá ser aplicado dentro do exercício financeiro subsequente, sob pena de acréscimo de $12,5 \%$ (doze inteiros e cinco décimos por cento) do valor previsto no inciso $\mathrm{V}$ do caput, a ser aplicado na mesma finalidade.

$38 \int 5^{\circ}$-A. A critério das agremiações partidárias, os recursos a que se refere o inciso $\mathrm{V}$ poderão ser acumulados em diferentes exercícios financeiros, mantidos em contas bancárias específicas, para utilização futura em campanhas eleitorais de candidatas do partido.

$\int 7^{\circ}$ A critério da secretaria da mulher ou, inexistindo a secretaria, a critério da fundação de pesquisa e de doutrinação e educação política, os recursos a que se refere o inciso V do caput poderão ser acumulados em diferentes exercícios financeiros, mantidos em contas bancárias específicas, para utilização futura em campanhas eleitorais de candidatas do partido, não se aplicando, neste caso, o disposto no $\mathbb{S} 5^{\circ}$. 
A inovação legal mostra-se extremamente importante na medida em que o financiamento eleitoral é um dos maiores desafios encontrados por candidatas, eis que suas campanhas normalmente contam com menores contribuições seja de doações, seja dos próprios partidos. Assim, a constituição prévia de um fundo com destinação específica para esse fim pode representar, na prática, a viabilização da campanha de mulheres que, de outra forma, não teriam condições de concorrer.

$\mathrm{O}$ art. $9^{\circ}$ da Lei $\mathrm{n}^{\circ} .13 .165 / 15$ estabeleceu que

"nas três eleições que se seguirem à publicação desta Lei, os partidos reservarão, em contas bancárias específicas para este fim, no mínimo $5 \%$ (cinco por cento) e no máximo $15 \%$ (quinze por cento) do montante do Fundo Partidário destinado ao financiamento das campanhas eleitorais para aplicação nas campanhas de suas candidatas, incluídos nesse valor os recursos a que se refere o inciso V do art. 44 da Lei no 9.096, de 19 de setembro de 1995 ”.

Contudo, ao julgar a ADI 5617, o Supremo Tribunal Federal deu “interpretação conforme à Constituição ao art. $9^{\circ}$ da Lei 13.165/2015 de modo a (a) equiparar o patamar legal mínimo de candidaturas femininas (hoje o do art. 10, $\mathbb{S}$ $3^{\circ}$, da Lei 9.504/1997, isto é, ao menos 30\% de cidadãs), ao mínimo de recursos do Fundo Partidário a lhes serem destinados, que deve ser interpretado como também de $30 \%$ do montante do Fundo alocado a cada partido, para eleições majoritárias e proporcionais, e (b) fixar que, havendo percentual mais elevado de candidaturas femininas, o mínimo de recursos globais do partido destinados a campanhas lhe seja alocado na mesma proporção".

A partir desse julgado, em controle concentrado, decisão semelhante foi tomada pelo Tribunal Superior Eleitoral quanto a distribuição dos recursos do Fundo Especial de Financiamento de Campanha (FEFC), previsto nos artigos 16-C e 16-D, da Lei das Eleições, e do tempo de propaganda eleitoral gratuita no rádio e na televisão, regulamentada nos arts. 47 e seguintes do mesmo diploma legal.

Em resposta à Consulta 253-18, o Tribunal determinou que os partidos devem observar os percentuais mínimos de candidatura por gênero, nos termos do art. $10, \mathbb{S} 3^{\circ}$, da Lei $n^{\circ} 9.504 / 97$, na linha da orientação firmada na Suprema Corte ao exame da ADI 5617. No caso de percentual superior de candidaturas, impõe-se o acréscimo de recursos do FEFC e do tempo de propaganda na mesma proporção.

\section{EFEITOS PRODUZIDOS PELA LEGISLAÇÃO}

O legislador brasileiro vem modificando o sistema normativo eleitoral, de modo a inserir na lei instrumentos voltados a promover uma maior participação feminina na política e, em última instância, conferir maior efetividade à isonomia de gêneros que, a despeito de prestigiada pela ordem constitucional (art. $5^{\circ}, \mathrm{I}$ ), nunca perpassou o plano teórico. 
Diante disso, faz-se necessário avaliar qual tem sido, na prática, os efeitos dessas novas regras, para que se possa verificar não só se a sua aplicação teve efetividade, mas também se os incentivos criados pelo legislador são suficientes para se alcançar uma igualdade representativa de gêneros.

No que tange à política de reserva de vagas de candidatura, o que se pode verificar é que, a despeito de ter efetivamente gerado um sensível aumento no percentual de candidaturas femininas, esse quadro não se refletiu no número de candidatas eleitas.

Destarte, conforme demonstram os dados do TSE, no ano de 1998, quando foram inicialmente implementadas as cotas, cerca de $10,4 \%$ dos candidatos ao cargo de deputado federal eram mulheres. Com a minirreforma de 2009, esse valor passou a ser de 19,1\% nas eleições de 2010, e chegou a 29,5\%, nas últimas eleições gerais, em 2014.

De outro lado, o percentual de mulheres eleitas para a Câmara dos Deputados nesse mesmo intervalo passou de $5,7 \%$ no ano de 1998 , para 9,0\% em 2010, chegando a 9,9\% em 2014.

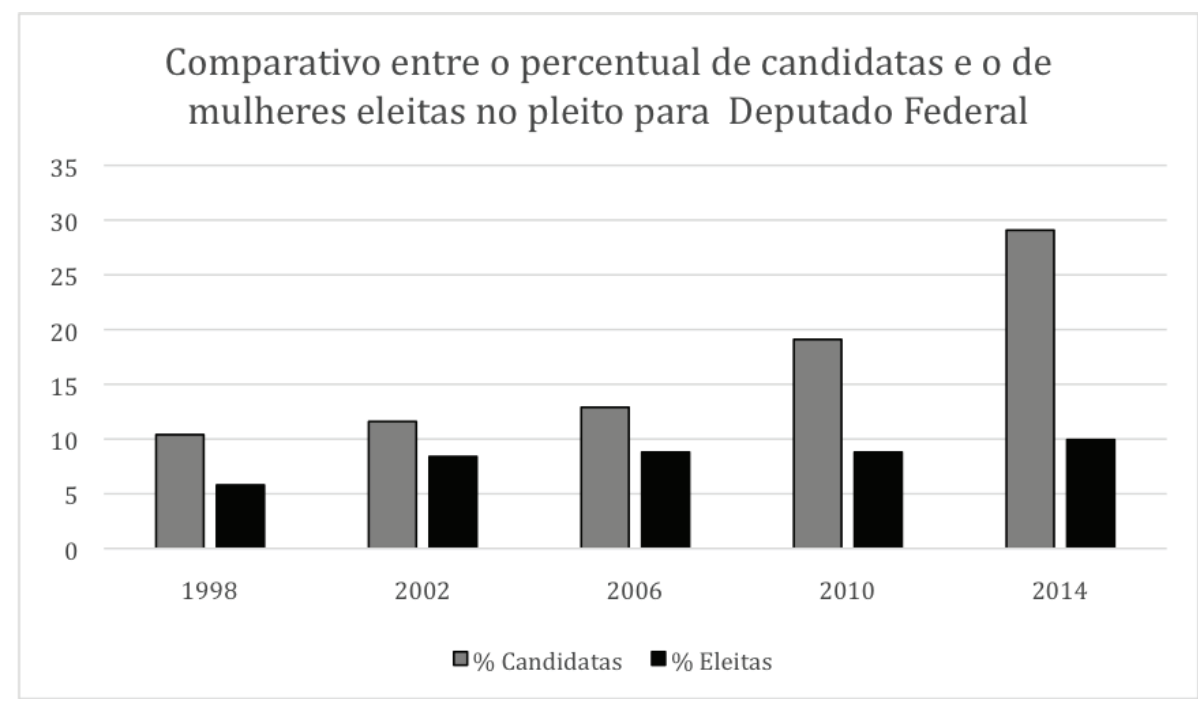

Dados do TSE. Elaboração própria.

Esse cenário se repete nas eleições para deputado estadual, em que o percentual de candidatas subiu de 13,1\% em 1998, para $21 \%$ em 2010 e $29,06 \%$ em 2014, todavia, o percentual de eleitas, nesse mesmo período foi de 10,2\%; $12,9 \%$ e $11 \%$, respectivamente. Vejamos: 


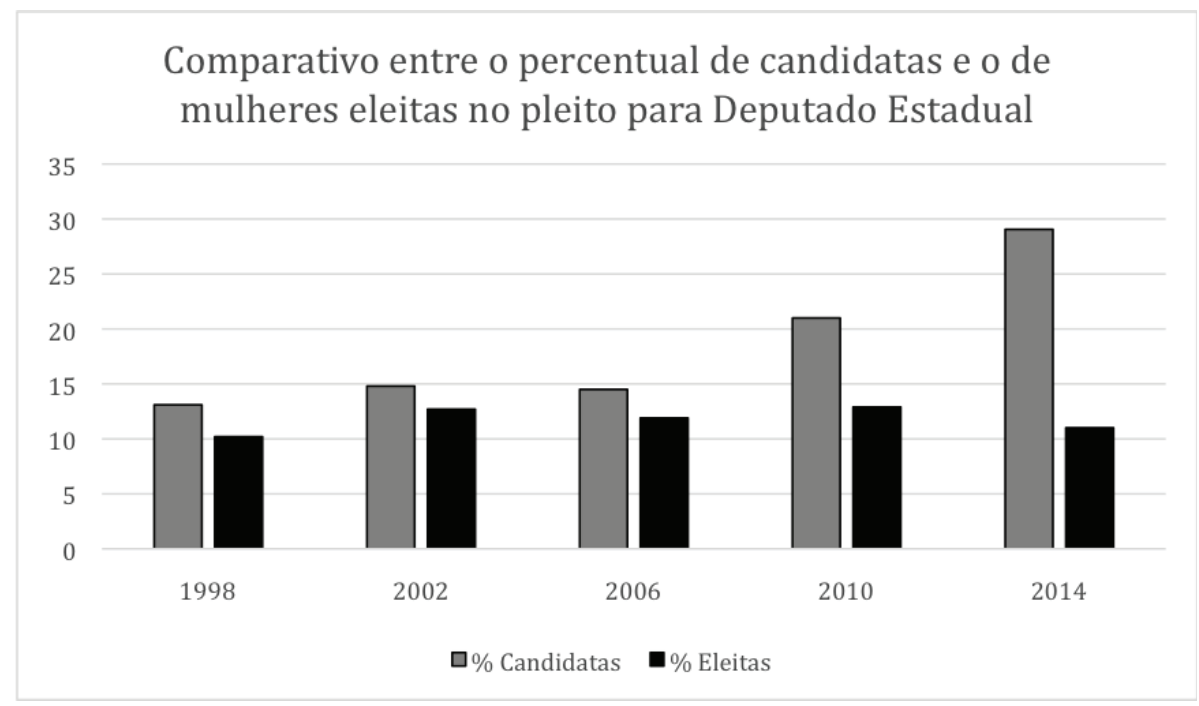

Dados TSE - Elaboração própria

Para além do fato de que o aumento na proporção de candidatas não ter implicado em um acréscimo correspondente no número de mulheres eleitas, pode-se notar também que esse número tem sofrido uma estabilização. Nas últimas três eleições, tanto para a Câmara dos Deputados quanto para as Assembleias Legislativas, o percentual de candidatas que lograram êxito em se eleger não variou mais do que 1 (um) ponto percentual.

No legislativo municipal, o quadro não é muito diferente: o percentual de mulheres eleitas em 2008 foi de $12,5 \%$, aumentou para $13,3 \%$ no ano de 2012, e não passou de 13,5\% nas eleições de 2016.

Os dados demonstram, portanto, que as cotas contribuíram sensivelmente para incrementar o número de candidaturas femininas a cargos de eleição proporcional. Todavia, permanece uma expressiva diferença no número de candidaturas masculinas e femininas e essa disparidade é ainda mais acentuada quando se analisa o número de eleitos.

Um dos fatores que certamente tem contribuído para esse quadro em que o incremento no número de candidatas não se reflete de forma proporcional no aumento de mulheres eleitas é a burla da norma, com os registros de "candidatura laranja”, prática que, conforme se explicitou, tem sido veementemente combatida pela Justiça Eleitoral, que passou a enquadrá-la como fraude eleitoral.

A magnitude desse lamentável fenômeno não o deixa passar despercebido. Segundo dados disponibilizados pelo TSE, nas eleições de 2016, 16.131 candidatos não tiveram nenhum voto, sendo que entre eles, 14.417 (ou 89\%), eram mulheres ${ }^{39}$.

39 Disponível em: < http://www.tse.jus.br/imprensa/noticias-tse/2016/Novembro/mais-de-16-mil- 
Outro fator que merece destaque quando se analisa o desempenho eleitoral das mulheres e a promoção de condições de disputa mais equânimes, diz respeito ao financiamento de suas campanhas, que possui função preponderante sobre as chances de sucesso nas eleições, já que a disponibilidade de recursos financeiros é fundamental para que o candidato possa desempenhar atividades centrais da campanha como organizar comitê, se comunicar com o eleitor e divulgar suas $\operatorname{propostas}^{40}$.

Como já destacado acima, as campanhas femininas são, em sua maioria, sub-financiadas, o que afeta diretamente o desempenho eleitoral das mulheres. Esse quadro foi minuciosamente analisado por Sacchet, cujo estudo apontou que, nas eleições de 2010, para o cargo de deputado estadual, o valor médio arrecadado por candidata foi de $\mathrm{R} \$ 58.561,00$. De outro lado, os homens arrecadarem em média R \$ 93.181,00, o que, em termos percentuais, indica uma arrecadação $37 \%$ menor pelas mulheres.

De acordo com a autora, a diferença foi ainda maior nas eleições para deputado federal, na qual as mulheres arrecadaram, em média, R\$107.281,00, enquanto os homens R \$ 234.776,00, indicando uma arrecadação 54\% menor das representantes do sexo feminino.

Em outro estudo, Sacchet e Speck ${ }^{41}$ verificaram que os partidos políticos constituem uma das maiores fontes de financiamento eleitoral no Brasil, tendo sido responsáveis por $19,6 \%$ do total recebido pelos candidatos a deputado federal nas eleições de 2010. Todavia, conforme constataram os autores, as agremiações, independentemente de sua linha ideológica, investem menos nas campanhas femininas:

(...) A maioria dos partidos, independentemente de sua linha ideológica tende a destinar parcelas significativamente maiores de seus recursos para candidatos homens e a diferença tem aumentado ao longo do tempo.

Diante disso, nota-se que, a despeito de estarem obrigados por lei a registrar campanhas femininas, os partidos, de forma geral, não têm se comprometido com a o sucesso de suas candidaturas, o que vai de encontro à busca por uma representação política mais igualitária em termos de gênero.

Um dos fatores que podem explicar o baixo grau de comprometimento das agremiações com a causa feminina é o fato de que suas estruturas internas são formadas por número bastante superior de homens. A despeito de alguns partidos estabelecerem em seus estatutos cotas para a participação feminina nos órgãos diretivos, o que se nota é que a maioria dos dirigentes partidários é formada por homens.

candidatos-tiveram-votacao-zerada-nas-eleicoes-2016>. Acesso em 11 de março de 2019 ..

40 SACCHET E SPECK, 2014, p. 422

41 Idem 2014, p. 433 
Analisando as Comissões Executivas dos dez partidos com maior representação na Câmara dos Deputados, verificou-se que apenas três deles possuem representantes do sexo feminino entre presidentes, vice-presidentes, secretários e tesoureiros ${ }^{42}$.

Esse quadro se torna alarmante quando se nota que esses dirigentes, na maior parte das vezes, pouco sensíveis aos interesses das mulheres filiadas, são os responsáveis por definir o destino dos recursos, quais os candidatos irão aparecer na propaganda partidária e, em última instância, quais serão as candidaturas efetivamente apoiadas pelo partido.

A discussão acerca da maior inclusão das mulheres entre os dirigentes partidários foi submetida ao Tribunal Superior Eleitoral na Consulta 060381639.2017.6.00.0000 e ainda encontra-se pendente de julgamento. Caso conheça da consulta, o Tribunal deve responder se a previsão de reserva de vagas para as candidaturas proporcionais deve ser observada para composição das comissões executivas e diretórios partidários.

A partir do que se expôs, é possível concluir que a despeito de ter havido um incremento no número de candidatas, o sistema normativo-eleitoral até aqui adotado, não tem sido eficiente para aumentar o percentual de mulheres eleitas. Todavia, longe de invalidar a importância das inovações legislativas, esse cenário serve para demonstrar que, para que haja um efetivo aumento no número de mulheres ocupando posições políticas, será necessária a implementação de outras medidas capazes de garantir condições mais isonômicas na disputa eleitoral.

\section{ACÕES AFIRMATIVAS PROPOSTAS PARA ALTERAÇÃO DO QUADRO DE SUBREPRESENTAÇÃO}

A adoção de ações afirmativas é sempre acompanhada de grande polêmica e algum desconforto, sobretudo por parte daqueles que não se encontram no núcleo de proteção. Não se pode perder de vista, contudo, que devem ter duração temporária com o único objetivo de corrigir injustiças históricas que, de outra maneira, não sairiam do ciclo de desigualdade. Essa a posição do Supremo Tribunal Federal nos casos julgados a respeito da matéria ${ }^{43}$.

42 A análise foi realizada a partir dos dados constantes nas páginas das agremiações na internet. Verificou-se a composição das Comissões Executivas dos seguintes partidos: PMDB, PT, PP, PSDB, PR, PSD, PSB, DEM, PTB e PRB.

Tendo em vista que a organização das estruturas intrapartidárias varia significativamente entre as agremiações, para possibilitar uma análise comparativa foram considerados apenas os seguintes cargos de direção: presidente, vice-presidentes, secretários e tesoureiros.

Dentre os partidos analisados, apenas no PT, PSDB e PDT havia mulheres ocupando os cargos de direção acima apontados.

43 ADC 41, Rel. Luís Roberto Barroso, DJe 8.6.2017; ADPF 186, j. em 26/4/2012, e RE 597.285, j. em 9/5/2012, ambos de relatoria do Min. Ricardo Lewandowski. 
Não é necessário grande aprofundamento histórico, como visto, para que se possa concluir que a sub-representação feminina em mandatos eletivos decorre de uma desequiparação histórica imposta às mulheres não apenas pela cultura, mas pelo próprio Estado de Direito, até há bem pouco tempo.

Mesmo as recentes decisões do STF na ADI 5717 e do TSE na Consulta 252$18^{44}$ impõe dúvidas sobre sua capacidade de converter os recursos empregados em um maior número de mulheres em cadeiras no parlamento, senão vejamos: i) os valores gastos pelas candidatas a vice e suplementes devem ser considerados no percentual destinado às mulheres? ii) a destinação de recursos poderá ser feita livremente pelos partidos para as candidaturas proporcionais e majoritárias? iii) se houver substituição de candidatura ou renúncia de candidatas eleitas, o valor empregado ainda será considerado válido?

Diante desse quadro, o presente artigo propõe-se a apontar algumas medidas que, longe de se pretenderem exaustivas ou definitivas, têm o objetivo de contribuir para o debate acerca dos caminhos a serem tomados pelo sistema político brasileiro na direção de uma realidade em que as mulheres possam efetivamente ser representadas nas esferas de poder do país.

Nessa direção, uma primeira proposta a ser considerada é a adoção de um sistema de cotas de representação, que consiste, basicamente, no estabelecimento de um percentual mínimo de cadeiras nas Casas legislativas a serem ocupadas por mulheres, em substituição à atual, e ineficiente, reserva de vagas de candidatura. Essa política é defendida por Eneida Desiree Salgado e Renata Caleffi ${ }^{45}$.

A medida tem como objetivo acelerar o processo de inserção das mulheres no cenário político partidário, tornando a representação no parlamento mais condizente com a distribuição de gênero verificada na sociedade, e pode ser gradualmente extinta conforme for se consolidando um quadro de igualdade de oportunidades entre os gêneros.

Apesar de haverem diferenças na forma de operacionalização, essa política é hoje aplicada em mais de 180 (cento e oitenta) países ao redor do mundo ${ }^{46}$. Nesse contexto, vale citar a proposta elaborada pelas professoras Eneida Desiree Salgado e Renata Caleffi (2015), para a adaptação da medida à realidade do

44 "A distribuição dos recursos do Fundo Especial de Financiamento de Campanha (FEFC), previsto nos artigos 16-C e 16-D, da Lei das Eleições, e do tempo de propaganda eleitoral gratuita no rádio e na televisão, regulamentada nos arts. 47 e seguintes do mesmo diploma legal, deve observar os percentuais mínimos de candidatura por gênero, nos termos do art. 10, $\mathbb{S} 3^{\circ}$, da Lei ${ }^{\circ}$ 9.504/97, na linha da orientação firmada na Suprema Corte ao exame da ADI 5617. No caso de percentual superior de candidaturas, impõe-se o acréscimo de recursos do FEFC e do tempo de propaganda na mesma proporção".

45 http://www.conjur.com.br/2015-mai-02/propostas-aumentar-participacao-feminina-politica

46 De acordo com dados da cartilha "+ Mulheres na Política”, desenvolvida em conjunto pela Procuradoria Especial da Mulher do Senado Federa e Secretaria da Mulher na Câmara. Disponível em: <https://www12.senado.leg.br/institucional/procuradoria/proc-publicacoes/ livreto-mais-mulheres-na-politica>. Acesso em 11 de março de 2019. p. 29 
sistema político brasileiro.

No Senado, cada estado possui três vagas, sendo que a cada quatro anos elas são renovadas parcialmente, em 1/3 e 2/3. Assim, a proposta das professoras é de que a aplicação das cotas ocorra nas renovações de $2 / 3$, quando necessariamente deverá ser eleita uma mulher. Para tanto, cada partido ou coligação terá necessariamente que registrar ao menos uma candidata, que irá disputar apenas com outras mulheres. Na outra vaga, não há reserva de gênero.

Nas eleições sob o sistema proporcional, Salgado e Caleffi apontam a possibilidade de adoção de listas fechadas, em que os partidos determinam previamente a ordem dos candidatos que ocuparão as cadeiras. Nesse modelo, o regime de cotas funcionaria com o estabelecimento da obrigatoriedade de que haja ao menos uma mulher a cada três nomes indicados.

As professoras ponderam, todavia, que esse modelo geraria não só uma redução no espectro de escolha do eleitor, mas também a concentração de um enorme poder nas mãos dos dirigentes partidários. Diante disso, sugerem um segundo formato, que consideram mais democrático, com a manutenção das listas abertas e a efetivação da reserva de vagas após o cálculo do quociente partidário.

Nesse caso, uma vez determinado o número de cadeiras a serem ocupadas por cada partido ou coligação, eles formariam internamente duas listas organizadas por ordem de votação, uma de mulheres e outras de homens, de forma que seriam necessariamente empossadas as mulheres mais votadas, no limite da cota adotada.

Para alcançar um número expressivo de mulheres no Poder Legislativo, sugerem a adoção de uma cota de $40 \%$ (quarenta por cento) das vagas obtidas pelo quociente partidário para as mulheres.

No bojo das discussões acerca da reforma política que atualmente se desenvolvem no Congresso Nacional, a PEC n ${ }^{\circ} 77 / 03$ propõe a implantação provisória de um sistema majoritário para a eleição na Câmara dos Deputados e Assembleias Legislativas, que vem sendo chamado de "distritão".

Trata-se de um sistema distrital plurinominal, em que há apenas um distrito na circunscrição eleitoral, ou seja, cada estado representa um único distrito. Assim, os candidatos mais votados no âmbito do Estado ou no Distrito Federal são eleitos.

A partir das eleições de 2022, o projeto prevê a adoção de um sistema distrital misto, que funcionaria da seguinte maneira: cada eleitor dispõe de dois votos, um em candidato registrado no distrito eleitoral, outro em uma lista partidária preordenada de candidatos; as cadeiras são dividas proporcionalmente a partir da quantidade de votos obtidos pelos partidos; parte dos representantes do partido deve ser eleito pelo princípio majoritário, em distritos uninominais, ocupando até a metade das cadeiras obtidas; as demais cadeiras serão ocupadas pelos candidatos que figuram nos primeiros lugares da lista partidária. 
No caso do chamado "distritão", por se tratar de eleições majoritárias em distritos plurinominais, a implantação das cotas é bastante simples, basta que se estabeleça o percentual mínimo de cadeiras que serão destinadas às mulheres, empossando-se as candidatas mais votadas no limite da cota adotada.

No caso do sistema distrital misto, pode-se estabelecer que nas listas preordenadas apresentadas pelos partidos, as posições contem com homens e mulheres de maneira intercalada, ou seja, se o primeiro candidato for homem, a segunda deve ser mulher, e assim por diante.

Portanto, o que se pretende assinalar é que, independente do sistema eleitoral que se venha a adotar, é possível - e necessário - que se adote medidas afirmativas para garantir a efetiva presença de mulheres nos cargos político-eletivos. Ainda que essas medidas tenham prazo para terminar até que o reequilíbrio se estabeleça e possamos romper a imobilidade do estado de desigualdade crônica - como se deu com a Lei 12.990/14 (quotas para negros nos concursos públicos federais), que vigorará pelo prazo de 10 anos.

Essa questão traz à tona a da fixação de cotas para mulheres na estrutura decisória dos partidos. A importância dessa medida torna-se clara quando se tem em mente que, no Brasil, inexiste a possibilidade de candidaturas avulsas, assim, os partidos são responsáveis pelo recrutamento e seleção de candidatos e por decisões que podem definir o sucesso das campanhas, como a alocação de recursos e a distribuição de tempo de propaganda ${ }^{47}$.

Ainda no que tange às modificações na estrutura interna dos partidos, voltadas ao combate do quadro de sub-representação feminina nas esferas decisórias, outra proposta que se apresenta é a obrigatoriedade de que as agremiações constituam secretarias da mulher, órgãos esses que tendem a gerar uma maior articulação política das mulheres no âmbito intra-partidário e, assim, fortalecer a sua atuação.

Por fim, sabendo que as punições e incentivos de natureza financeira costumam ser extremamente eficazes no sentido de reprimir ou estimular condutas, poder-se-ia utilizar também desse método para promover uma maior representação feminina na política. Nessa direção, propõe-se o desconto de parcelas do Fundo Partidário para as agremiações que não observarem as cotas previstas na legislação ou, ao inverso, uma política de distribuição do Fundo Partidário que premie agremiações de acordo com o percentual de mulheres eleitas.

Diversos países já adotam políticas dessa natureza. Na França, por exemplo, se a diferença de gênero entre os candidatos de um partido é maior do que $2 \%$ (dois por cento) o financiamento público é reduzido em 3/4 (três quartos) dessa diferença. No Quênia, os partidos não recebem financiamento público se mais de 2/3 de seus titulares de cargos registrados forem do mesmo sexo e, no

47 SACCHET, 2011, p. 162 
Níger, $10 \%$ (dez por cento) do financiamento público é distribuído proporcionalmente ao número de mulheres eleitas por cotas. Na Argentina há cotas de gênero no percentual de $5 \%$, desde $2011^{48}$.

Nota-se, portanto, que são numerosas as medidas capazes de incentivar as participação das mulheres na política e conferir-lhes espaço para que efetivamente passem ocupar cargos decisórios, o que é essencial não só para enriquecer o debate político, acrescenta-lhe novas perspectivas, mas também para fortalecer o sistema democrático como um todo, tornando-o mais representativo.

\section{CONCLUSÃO}

O presente artigo buscou inicialmente demonstrar a gravidade do quadro de sub-representação feminina nas instâncias político-decisórias. Para tanto foram expostos dados que demonstram que, apesar de ser maioria em termos populacionais e terem alcançado níveis de educação formal tão elevados quanto os dos homens, as mulheres constituem uma minoria política e possuem percentuais baixíssimos de representantes nas esferas de poder seja a nível federal, estadual ou municipal, em cargos de eleição majoritária ou proporcional.

Diante desse quadro, o segundo tópico do artigo dedicou-se a perquirir as causas da baixa representatividade feminina na política, tendo sido possível identificar fatores de diferentes ordens: sistêmica, cultural, e institucional.

Evidenciado o problema e suas causas, passou-se a expor as medidas que vêm sendo implantadas no sistema jurídico-eleitoral, com vistas a atenuar esse grave quadro de sub-representação feminina no cenário político brasileiro, analisando-se ainda a forma como o Tribunal Superior Eleitoral tem realizado a interpretação e aplicação dessas leis.

Em seguida, passou-se a analisar a efetividade de tais regras na promoção de uma maior representatividade das mulheres em cargos político-decisórios. Constatou-se que as medidas até aqui implantadas, a despeito de terem gerado algum avanço no sentido de incrementar o número de candidatas nas eleições, têm sido pouco efetivas na promoção de um maior debate e conscientização acerca da importância da participação feminina na política e geraram mudanças extremamente modestas no que tange ao acréscimo no número de mulheres que ocupam cargos eletivos.

A partir de tal constatação, expôs-se as medidas propostas pela doutrina e pelo legislativo e que são voltadas a promover, de maneira mais efetiva, a modificação desse lamentável quadro de sub-representação feminina, que hoje macula a democracia brasileira.

Por fim, conclui-se que sem a adoção de ações afirmativas que garantam a efetiva participação feminina em mandatos eletivos por meio de cotas que

48 BALLINGTON E KAHANE, 2015, p. 424-425 
reservem as cadeiras por período de transição - sejam eles do executivo ou do legislativo, não haverá superação das profundas desigualdades de gênero que ainda hoje constituem uma infeliz realidade no Brasil.

Essa não é uma análise pouco complexa. Repensar a origem do problema da sub-representação feminina na política, levantando suas causas é certamente um passo de extrema importância para que se possa vislumbrar caminhos de superação. Para compreender a sub-representação feminina na vida política brasileira, não se pode perder de vista que até 1962 a mulher era considerada relativamente incapaz e dependia do seu marido para exercer inúmeros direitos.

Daí para frente o histórico de desequiparação legal entre homens e mulheres vem diminuindo em todas as áreas, menos na política. A se considerar as pesquisas atuais, essa sub-representação não decorre de um fator natural simplesmente porque as mulheres não querem participar da política. Esse cenário decorre dessa complexidade de fatores e, sobretudo, de uma história que posicionou os homens em grande vantagem frete às mulheres.

Como, claro, quem ocupa posição de poder não quer sair e as regras são definidas por quem lá está, o ciclo de desequiparação nunca será interrompido a não ser por uma decisão externa a esse ciclo vicioso. Exatamente aqui, como fator de ruptura, entra a importância das ações afirmativas (como as quotas de gênero).

Os homens, evidentemente, não tem incentivo algum para alterar regras que favoreçam a participação feminina; ao contrário, querem aprovar projetos como esse que revogam a ação afirmativa mais importante nessa matéria. $\mathrm{O}$ reconhecimento constitucional e legal da igualdade entre homens e mulheres não foi suficiente para assegurar que as mulheres ocupassem o mesmo espaço que os homens na representação democrática. Apesar dos exemplos de sucesso na implementação de medidas efetivas para a maior inclusão de mulheres nos centros de poder, é inacreditável que ainda haja quem pretenda revogar as ações afirmativas que vigoram nesse sentido.

Como visto, no Brasil, é muito recente a implantação de mecanismos que buscam romper essa desigualdade. Apesar de as reformas eleitorais com imposição de quotas estarem previstas na Lei 9.504/1997, somente depois de 2009, com a alteração de posicionamento do TSE, é que se tornaram mais efetivas.

Não há solução fácil e única para um problema tão profundo e complexo. Mas é certo que essas medidas devem ser mantidas e ampliadas até que a disputa por uma cadeira no poder executivo ou no poder legislativo seja equilibrada. A supressão de qualquer ação afirmativa nesse momento seria um absoluto retrocesso, incompatível com a pretensão constitucional.

\section{REFERÊNCIAS}

ARAÚJO, C. Cotas femininas e financiamento de campanha. In: Cadernos Adenauer, Ano 14, n. 3, pp.11-29. 
BALLINGTON, J.; KAHANE, M. Mulheres na política: financiamento para a igualdade de gênero. In: FALGUERA, E.; OHMAN, M.; JONES, S. (Orgs) Financiamento de partidos políticos e campanhas eleitorais. São Paulo: International IDEA/FGV, 2015, pp.399-455.

BRASIL. Tribunal Superior Eleitoral. Impugnação ao registro de candidatura. Recurso Especial Eleitoral $n^{\circ} 11781$. Coligação Ribeira no Coração e Ministério Público Eleitoral. Relatora Min. Nancy Andrighi. Publicado em sessão: 06 nov 2012.

BRASIL. Tribunal Superior Eleitoral. Registro de candidatura. Recurso Especial Eleitoral no 2939. Coligação Frente Renovadora pela Decência Política e Justiça Social e Ministério Público Eleitoral. Relator Min. Arnaldo Versiani. Publicado em sessão 06 nov 2012.

BRASIL. Tribunal Superior Eleitoral. Ação de impugnação de mandato eletivo. Corrupção ou fraude. Recurso Especial Eleitoral $n^{\circ} 149$. Coligação vitória que o povo quer e José Luiz de Souza. Relator Min. Henrique Neves da Silva. Diário de Justiça Eletrônico 21 out 2015.

BRASIL. Tribunal Superior Eleitoral. Ação de investigação judicial eleitoral. Abusdo de poder econômico e político. Recurso Especial Eleitoral n ${ }^{\circ} 24342$. Coligação vitória que o povo quer e Coligação por um novo tempo. Relator Min. Henrique Neves da Silva. Diário de Justiça Eletrônico 11 out 2016.

COSTA, T. C. Cotas de participação e eleições no Brasil. In: PAIVA, D.; BEZERRA, H. D. (Orgs). Mulheres, política e poder. Goiânia: Cânone Editorial, 2011.

GOMES, J. J. Direito Eleitoral. 12ª ed. São Paulo: Atlas, 2016.

DAHLERUP, D. El Uso de cuotas para incrementar la representación política de la mujer. In: MENDÉZ-MONTALVO, M.; BALLINGTON, J. Mujeres en el Parlamento. Más allá de los números. Estocolmo: International IDEA, 2002, pp.159-172.

SACCHET, T. Partidos políticos e sub-representação feminina: um estudo sobre recrutamento legislativo e financiamento de campanhas no Brasil. In: PAIVA, D.; BEZERRA, H. D (Orgs). Mulheres, política e poder. Goiânia: Cânone Editorial, 2011.

SAlGADO, E. D; GUIMARÃES, G. A.; MONTE-AlTO, E. V. L. C. Cotas de Gênero na política: entre a história, as urnas e o parlamento. In: Gênero e Direito, $\mathrm{n}^{\mathrm{o}}$ 03. João Pessoa: 2015, pp. 156-182.

SALGADO, E. D.; CALEFFI, R. Propostas para aumentar a participação feminina na política brasileira [on line]. Mai. 2015. Disponível em: < http://www.conjur. com.br/2015-mai-02/propostas-aumentar-participacao-feminina-politica $>$. Consulta em 14.08.2017.

Recebido em: 20/06/2018.

Aprovado em: 11/03/2019. 